\title{
Composition and Structure of Mangrove Vegetation on Baai Island, West of Sumber Jaya Village, Kampung Melayu District, Bengkulu City
}

\author{
Fatimatuzzahra $^{1 *}$ Jarulis $^{1}$, Rochmah Supriati ${ }^{1}$ \\ ${ }^{1}$ Departement of Biology, Faculty of Matemathics and Natural Sciences, Universitas Bengkulu, Kandang Limun, \\ Bengkulu 38371, Indonesia \\ *Corresponding author.Email: fatimatuzzahra@unib.ac.id
}

\begin{abstract}
Mangroves have an important role both ecologically and economically, so their existence is very necessary to maintain the stability of the mangrove ecosystem. Therefore, data related to the composition and structure of mangrove vegetation are needed. The observation location is on Baai Island, west of Sumber Jaya Village, Kampung Melayu District, Bengkulu City. Sampling was carried out in August 2020 by purposive sampling with the plotline transect method for tree, pole, sapling, and seedling levels. The results of observations and calculations showed that 3 families were found consisting of the Rhizophoraceae, Avicenniaceae, and Sonneratiaceae families with 4 plant species having the highest important value index (INP), namely Bruguiera sexangula with an INP value of 141.02 for the tree level, Rhizophora apiculata with an INP value of 165.28 for the pole level, and Avicennia marina with an INP value of 130.56 for the sapling level and the highest for the seedling level with an INP value of 103.70
\end{abstract}

Keywords: Vegetation Composition and Structure, Mangrove, Baai Island

\section{INTRODUCTION}

Baai Island is one of the conservation areas which is managed under the Bengkulu KSDA Office. It has a variety of natural beauty, both the beauty of flora and fauna [1]. The potential area seen from the point of view of flora is the vegetation formation that makes up the coastal forest around Baai Island, one of the three vegetation formations is mangrove forest. One of the supporting villages of the Pulau Baai Nature Park, which has mangrove forests, is the western part of Sumber Jaya Village, Kampung Melayu District, Bengkulu City.

The location being observed is to the left of the entrance to the tourist area towards the red lantern. Based on preliminary observations, the mangroves around this location are increasingly damaged, both naturally and by human intervention. So, it is necessary to collect data related to the composition and structure of mangrove vegetation to maintain forest sustainability mangroves around this location until the future.

\section{MATERIALS AND METHODS}

Data collection was carried out in AugustNovember 2020 in the Pulau Baai area, the western part of Sumber Jaya sub-district, Kampung Melayu District, Bengkulu City (Figure 2). Sampling was carried out by purposive sampling with the transect line plot method towards the water. The size of the plot used is $20 \times 20 \mathrm{~m}$ for the tree level, $10 \times 10 \mathrm{~m}$ for the pole level, $5 \times 5 \mathrm{~m}$ for a sapling, and $2 \times 2 \mathrm{~m}$ for the seedling level.

The tools used are GPS, Thermo hygrometer, hand refractometer to measure salinity, roll meter, and identification guide book for mangrove introduction in Indonesia [2]. 


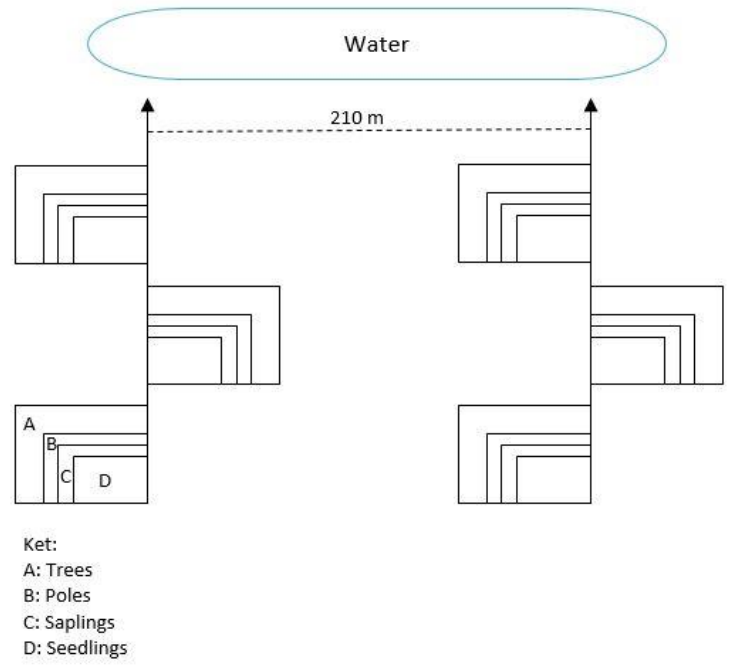

Figure 1. Data collection path design

\section{RESULT AND DISCUSSION}

\subsection{Mangrove Vegetation Composition}

Based on observations of mangrove vegetation on Baii Island, found 3 families consisted of the Rhizophoraceae, Avicenniaceae, and Sonneratiaceae families.

Family Rhizoporaceae was found to dominate in the observation area. This is supported by the number of species found in the sampling area as many as 2 species, namely Bruguiera sexangula and Rhizophora apiculata with quite a lot (Table 1). Based on field observations, these species are mostly found in areas of fine muddy soil, which are also inundated during normal tides.

\subsection{Mangrove Vegetation Structure}

Mangrove plant species found in the sampling area were Bruguiera sexangula, Avicennia marina, Rhizophora apiculata, Sonneratia alba. The high relative density (DsR) values at the tree and pole levels come from the Rhizophoraceae family, this value indicates that the habitat at the sampling location strongly supports the existence of this family. Meanwhile, for sapling and seedling levels, the highest density value or relative density was owned by the Avicennia marina, which originated from the Avicenniaceae family.

The species Avicennia marina and Rhizophora apiculata can be found at each level, namely from the tree-seedling level, but different from Bruguiera sexangula, and Sonneratia alba. Bruguiera sexangula was not found at sapling and seedling levels, while Sonneratia alba was found at a seedling level in plot 6; however, when viewed in the field, this species was found mostly in the middle towards the roadside ( $\pm 40 \mathrm{~m}$ towards the roadside) but its presence was outside the collection plot sample.

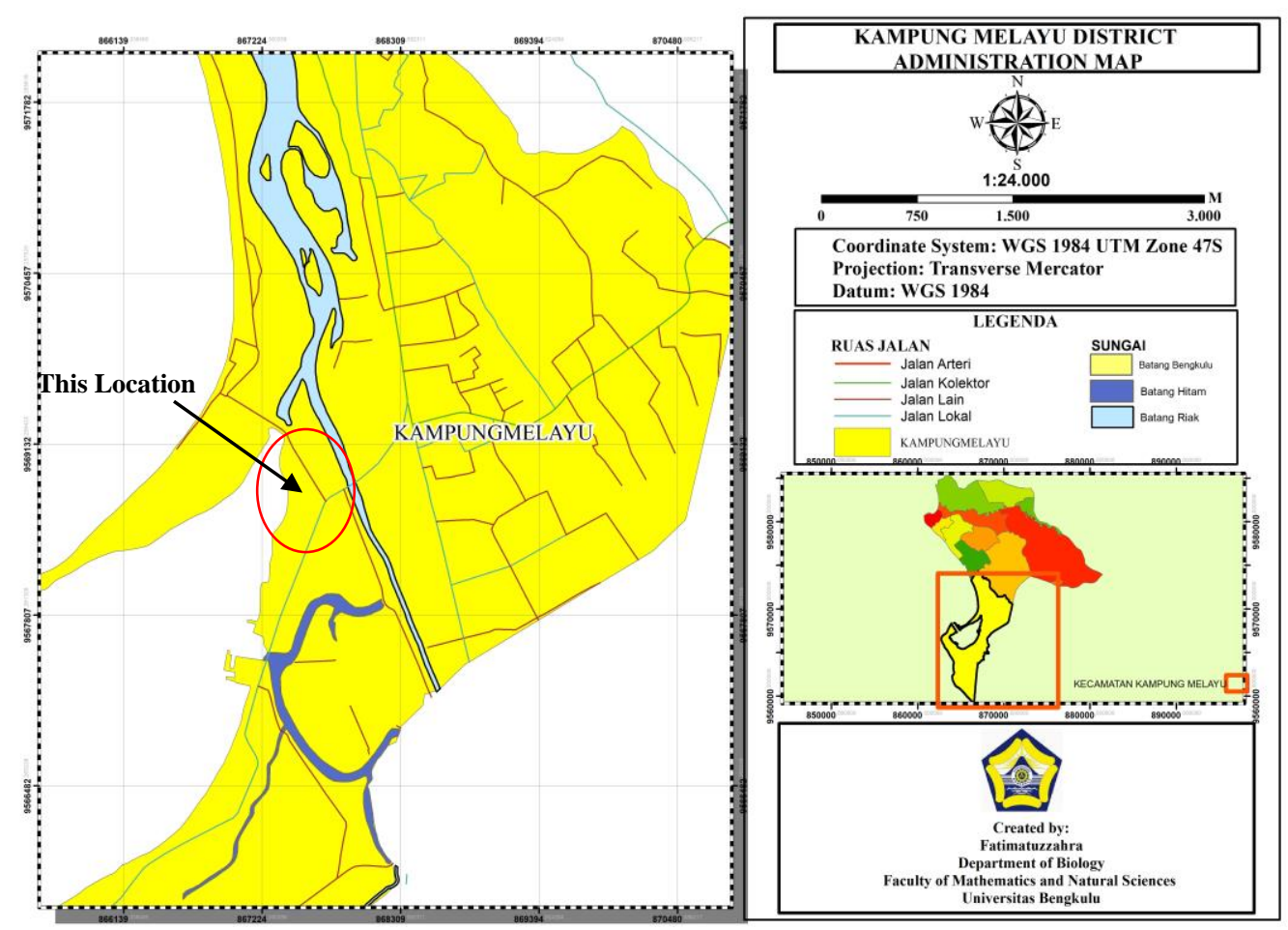

Figure 2. The mangrove research locations 
Table 1. Vegetation composition of trees, poles, saplings, seedlings (number of families, species, and individuals)

\begin{tabular}{cccccccc}
\hline \multirow{2}{*}{ No } & \multirow{2}{*}{ Family } & \multirow{2}{*}{ Total Species } & Trees & Poles & Saplings & Seedlings & Total Individu \\
\hline 1 & Rhizophoraceae & 2 & 50 & 55 & 6 & 43 & 154 \\
2 & Avicenniaceae & 1 & 17 & 38 & 18 & 61 & 134 \\
3 & Sonneratiaceae & 1 & 0 & 0 & 0 & 2 & 2 \\
\hline
\end{tabular}

Sonneratia alba is a pioneer species, intolerant of freshwater for a long period, likes soil mixed with mud and sand, sometimes on rocks and corals. Often found in coastal locations protected from the impact of waves, as well as in estuaries and around offshore islands [2].

One of the indicators used to examine forest structure is tree size data which includes the circumference or diameter of the trunk.

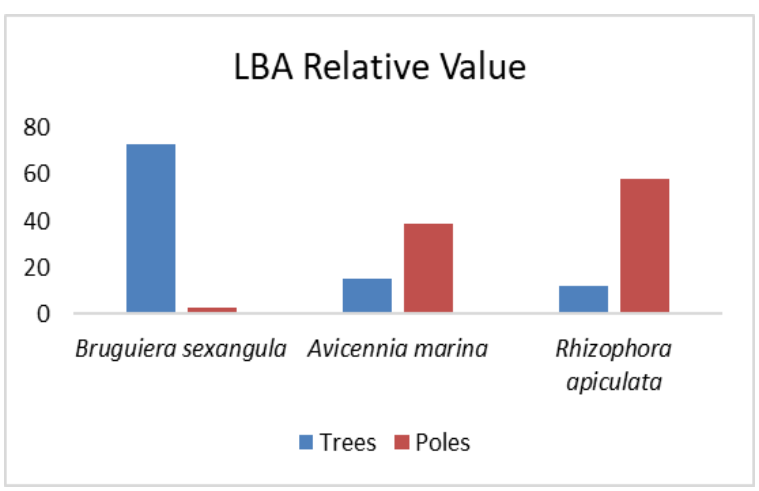

Figure 3. Relative LBA Value

Based on Figure 3, it can be seen that the relative variety of LBA values shows the influence of the plant environment such as humidity and temperature, competition for nutrients, sunlight, and growth space, as well as other types that greatly affect the growth of tree trunk and pole diameters [3]. The basal area is also influenced by the type and age of the tree [4].

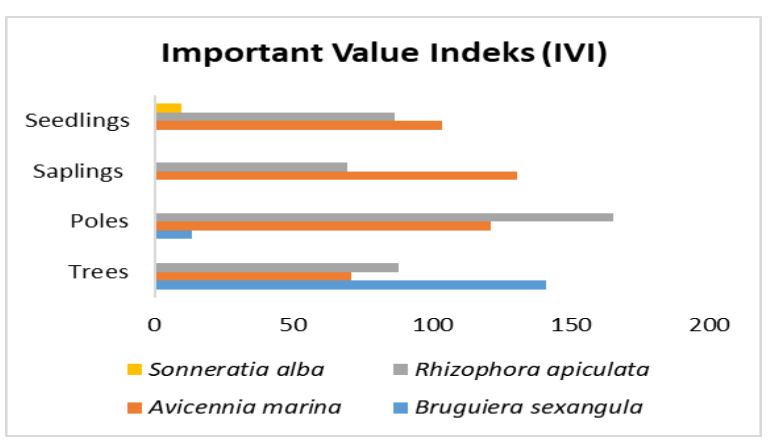

Figure 4. Important Value Index of growth form levels
Regarding the Importance Value Index (IVI) in Figure 4. So, for the tree level, Bruguiera sexangula had the highest IVI value compared to other species, but for the pole level Rhizophora apiculata species had the highest IVI value, and Avicennia marina had the highest IVI value from sapling and seedling levels. The Importance Value Index (IVI) illustrates the importance of the role of a type of vegetation in an ecosystem, namely affecting the stability of the ecosystem [5].

\subsection{Environmental Parameters}

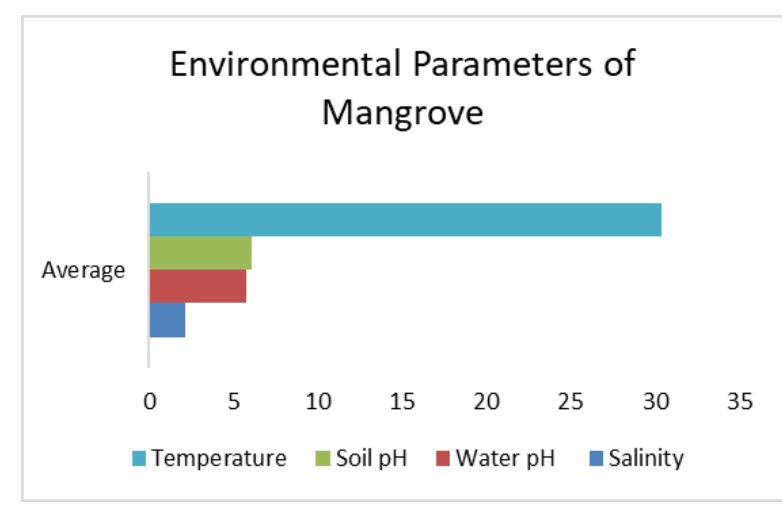

Figure 5. Environmental Parameters of Mangrove

The existence of the mangrove ecosystem cannot be separated from the environmental conditions which are a supporting factor to support the life of mangrove vegetation. Observation of environmental parameters measured in the form of temperature, soil $\mathrm{pH}$, water $\mathrm{pH}$ and salinity. Figure 5 shows the average temperature in the observation area of $30.5^{\circ} \mathrm{C}$. Temperature could be affected by physiological processes such as photosynthesis and respiration [6].

The soil $\mathrm{pH}$ measured in the plot area has an average of 6.07. Soil $\mathrm{pH}$ with a value range of 6-7 is a suitable $\mathrm{pH}$ for mangrove growth [7]. Soil $\mathrm{pH}$ is related to the suitability and ability of the soil to absorb water, penetration of mangrove roots, and nutrient binding [8]. 
Water $\mathrm{pH}$ obtained from measurements in the sampling area, the average value is 5.74. The high and low $\mathrm{pH}$ is influenced by the content of $\mathrm{O}_{2}$ and $\mathrm{CO}_{2}$ that enters the waters. In addition, the decrease in $\mathrm{pH}$ is also influenced by the decrease in $\mathrm{OH}^{-}$ions in the waters and the increase in the concentration of $\mathrm{H}^{+}$ions into the waters. When sampling water $\mathrm{pH}$, the current state began to recede, thereby affecting the $\mathrm{pH}$ value of the water obtained. Sediment physical factors can affect the $\mathrm{pH}$ value, the smaller the grain size of the sediment, the lower the $\mathrm{pH}$ [9].

Measurement of salinity in the sampling area is in the range of 1-2. Salinity in the waters of the mangrove is low because, at the time of data collection, the state of the waters was receding and the location of mangrove vegetation in 4-6 plots is adjacent to the bridge that connects freshwater (rivers) to the sea. So then, freshwater crossed into the area of mangrove vegetation and because water salinity to be low.

\section{CONCLUSION}

Based on observations made in the mangrove area of Baai Island, west of Sumber Jaya village, Kampung Melayu sub-district, three families were found consisting of the Rhizophoraceae, Avicenniaceae, and Sonneratiaceae families with 4 plant species having the highest Important Value Index (IVI), namely Bruguiera sexangula with IVI 141.02 for levels of the tree, Rhizophora apiculata with IVI 165.28 for levels of the pole, and Avicennia marina with IVI 130.56 for stake levels are also highest levels of seedling with IVI value of 103.70 which environmental factors came affected the existence of mangrove vegetation.

\section{REFERENCES}

[1] Balai Konservasi Sumber Daya Alam Bengkulu. 2017, Accessed on 26 Oktober 2020 https://bksdabengkulu.id/profil/kawasan/5 [In Bahasa Indonesia]

[2] Noor, YR., M.Khazali, I.N.N Suryadiputra. 2006. Panduan Pengenalan Mangrove di Indonesia. Bogor. PHKA/ WI-IP. [In Bahasa Indonesia]

[3] Saputra, A. 2013. Analisis Struktur Vegetasi Pohon di Sekitar Mata-Air yang berpotensi Untuk Konservasi Mata Air. Tesis. Program Studi Biologi Pascasarjana UGM. Yogyakarta. [In Bahasa Indonesia]
[4] Astuti, I.P., Eka F.T., and Sugeng, B. Keanekaragaman Jenis dan Ekologi SirihSirihan Liar Anggota Suku Piperaceae di Kawasan Hutan Lindung BPKH Gunung Slamet Barat dan BKPH Moga. Prosiding Seminar UPT Balai Konservasi Tumbuhan - Cibodas. Konservasi Tumbuhan Tropika: Kondisi Terkini dan Tantangan ke Depan, 2011, p.205-2011. [In Bahasa Indonesia]

[5] Fachrul, M.F. Metode Sampling Bioekologi. Bumi Aksara, 2007. [In Bahasa Indonesia]

[6] Alwidakdo, A., Zikri. A., and Legowo. K. 2014. Studi Pertumbuhan Mangrove Pada Kegiatan Rehabilitasi Hutan Mangrove Di Desa Tanjung Limau Kecamatan Muara Badak Kabupaten Kutai Kartanegara. Jurnal Agrifor 13 (1): 11-18. DOI: https://doi.org/10.31293/af.v13i1.543 [In Bahasa Indonesia]

[7] Fajar, A., Oetama, D., Afu, A. 2013. Studi Kesesuaian Jenis untuk Perencanaan Rehabilitasi Ekosistem Mengrove di Desa Wawatu Kecamatan Moramo Utara Kabupaten Konawe Selatan. Jurnal Mina Laut 3(2). [In Bahasa Indonesia]

[8] Azis, R., I Nengah K., Bau T. 2017. Kondisi Fisik Tanah Hutan Mangrove Di Desa Dolago Kecamatan Parigi Selatan Kabupaten Parigi Moutong. Jurnal Warta Rimba 5(1): 37-42. [In Bahasa Indonesia]

[9] Mathius, R. S., Bonny L., and Modesta R.M. 2018. Pengaruh Faktor Lingkungan Terhadap Keberadaan Gastropoda Pada Ekosistem Mangrove Di Dermaga Lantamal Kelurahan Karang Indah Ditrik Merauke Kabupaten Merauke. Musamu Fisheries and Marine Journal 1(2): 33-48. DOI: https://doi.org/10.35724/mfmj.v1i1.1440. [In Bahasa Indonesia] 